\title{
Adsorption as a Process for Produced Water Treatment: A Review
}

\author{
Roghayeh Yousef ${ }^{1}$, Hazim Qiblawey ${ }^{1, * \mathbb{D}}$ and Muftah H. El-Naas ${ }^{2}$ (D) \\ 1 Department of Chemical Engineering, Qatar University, Doha P.O. Box 2713, Qatar; \\ rd1105246@student.qu.edu.qa \\ 2 Gas Processing Center, College of Engineering, Qatar University, Doha P.O. Box 2713, Qatar; \\ muftah@qu.edu.qa \\ * Correspondence: hazim@qu.edu.qa
}

Received: 14 October 2020; Accepted: 30 November 2020; Published: 16 December 2020

check for updates

\begin{abstract}
Produced water (PW) is a by-product of oil and gas operations, and its production is foreseen to increase in the upcoming years. Such an increase is justified by various entities through their projection of the expected increase in the demand of oil and gas. The treatment of produced water is a significantly growing challenge for the oil and gas industry that requires serious attention. The first part of this review will present the underlying issue of produced water and relevant practices. With adsorption being defined as the least expensive treatment method, the second part will introduce general adsorption principals. The third part will describe the recent applications of adsorption for the treatment of PW with more focus of categorizing the adsorbents as natural and non-natural adsorbents. The main aim of this review is to shed light on the recent research related to PW treatment using adsorption. This is performed to highlight the shortcomings in PW adsorption research and recommend research pathways that can help in developing the field further.
\end{abstract}

Keywords: adsorption; produced water; water treatment; oil water; separation

\section{Introduction}

Large amounts of wastewater are generated during the oil and gas operations, and they are often referred to as produced water (PW). It is basically a combination of the water originally exiting in the wells, which is the formation water, and any additional water injected for enhanced oil and gas recovery. By far, this water is the largest produced volume by industry and can accommodate different contaminants, such as oil compounds, dissolved minerals, chemical compounds and dissolved solids [1-4]. The contaminants constituting PW can vary drastically depending on the geolocation and the petroleum product obtained [5]. To showcase this variation, Table 1 shows a sample of PW concentrations and how they vary depending on the country. Based on this variation, it is difficult to assign generic characteristics to PW and its contaminants.

Table 1. Examples of PW concentrations.

\begin{tabular}{ccc}
\hline PW Source & Hydrocarbon Concentration (mg/L) & Reference \\
\hline Yangtze Petrochemical Company (China) & 6000 & {$[4,6]$} \\
Oil India Limited (India) & 366 & {$[4,7]$} \\
Brazilian Oil Production (Brazil) & 250 & {$[8,9]$} \\
BP AG Refinery (Germany) & $200-1000$ & {$[8,10]$} \\
\hline
\end{tabular}


PW contaminants could have detrimental effects on the aquatic environment, as this contaminated water is often discharged to surface water, especially for offshore operations. Depending on the geolocation of the discharge, a specific regulatory limit stands for the amount of contaminant present in PW [11,12]. Thus far, most countries in Europe, North/South America and the Middle East adopted near zero discharge regulations [13-17]. These regulations vary and in Table 2, it is shown how PW discharge regulations differ depending on the country of operation.

Table 2. Hydrocarbon discharge regulations in different countries.

\begin{tabular}{ccc}
\hline Country & Hydrocarbon Discharge Regulatory Level (mg/L) & Reference \\
\hline U.S.A & 42 & {$[15,16]$} \\
Australia & 30 & {$[15,17]$} \\
Colombia & 15 & \\
Argentina & 5 & \\
\hline
\end{tabular}

Discharge level is a topic of importance in the oil and gas industry due to the projected increase in demand for energy [18]. According to the IEA, the need for fossil fuel is expected to grow drastically in the upcoming years [19]. As a result, it is foreseen that the amount of PW from the oil and gas industry will increase [18]. The expected increase of PW is mainly related to two factors: (i) increased production of oil/gas and (ii) age of the oil/gas field. With these two factors, the increase of PW is projected to be more than the current levels $[1,12,18]$. Based on this expected increase, a treatment method that can handle large volumes of PW is required and this is while economically covering a range of contaminants. With these requirements and based on the literature available, the adsorption approach is the best treatment option that can deliver these requirements for PW. Adsorption treatment approach is reported to operate at low concentrations with less operation time and much lower cost than other treatment methods $[20,21]$. Lowering the cost of treatment gives potential to PW for reuse in several practices. Such practices can range from injection into petroleum wells to industrial and domestic usages [16]. Managing PW by reusing it gives an incentive to industries, as treatment assigns a value to $\mathrm{PW}$ in the economy [5].

While most previous adsorption review papers consider generalized point of views related to the adsorption process, this review focuses on the application of adsorption for produced water treatment. The aim is to evaluate the current output of PW adsorption research and present the potential of recent adsorption system studies. It is important to note that the inclusion of heavy metals in this review is based on the point view that heavy metals are potential contaminants in PW. Depending on the geolocation of PW, these metals can vary between barium, lead, copper, cadmium, chromium, iron, arsenic, mercury and zinc [22-25]. With an emphasis on these heavy metals being part of PW, this review paper will discuss adsorbent systems that target heavy metals and hydrocarbons. The first part of this review will explain the main principles of adsorption and how it is reported in the literature. The second part will focus on the adsorbents investigated with respect to PW and their main reported results. Finally, research recommendations from the authors' point-of-view are stated for the guidance on how the field of PW adsorption should evolve.

\section{Adsorption}

In the literature, the materials used for PW are commonly assessed by characterization, kinetics and isotherms [26]. On a molecular level, adsorption is a process where attractive forces associate a solute (adsorbate) to a solid surface (adsorbent). The solid material used for the adsorption consists of a porous medium with a high internal surface area [27]. It is a common practice in the literature to describe these solid media by the parameters shown in Figure 1. 


\section{Common Adsorbent Assessments}

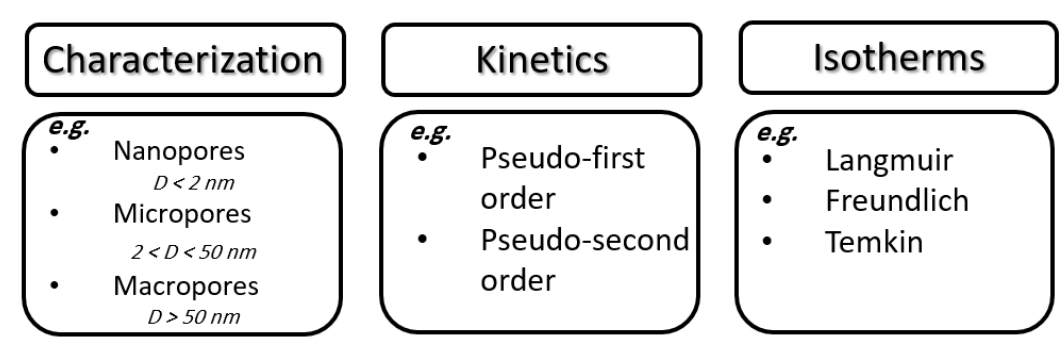

Figure 1. Common parameters for describing adsorption systems in the literature.

\subsection{Characterization}

To gain a microscopic insight into how adsorption of PW contaminant occurs, characterizing the adsorbent system is often necessary. A solid with a good adsorption capacity should exhibit explicit characteristics that are related to the adsorbent's surface area and internal network of pores [27]. According to IUPAC, an adsorbent can satisfy these characteristics by having a pore size between $2 \mathrm{~nm}$ to $50 \mathrm{~nm}[28]$.

\subsection{Kinetics}

Through the PW related literature, various studies have reported the kinetics of the adsorption system through conducting time interval experiments. These experiments are based on withdrawing a sample at specified time intervals and measuring the concentration [29]. The obtained data are used to build a profile and fit a suitable kinetics model that can describe the adsorption system. Based on the model, the adsorption mechanism can be identified [30]. From the many different kinetics models, the most common models in PW adsorption were observed to be: pseudo-first order, pseudo-second order, intraparticle diffusion model [31]. In terms of the pseudo-first order, if this model is confirmed by the experimental data, adsorption is taking place through physical forces [32]. With regards to pseudo-second order, using this model to fit the experimental data well, declares that adsorption mechanism is occurring through chemical means [33]. To further explore the chemical means, Elovich model is suggested as a kinetic model in the PW literature. This model accounts for predicting the mass and surface diffusion along activation energies [34]. Proportionate to the pseudo orders and Elovich model, the intraparticle diffusion model is a kinetics model with multiple mentions in the literature. This model is an indication that the intraparticle diffusion is the rate limiting step for adsorption. This is with the experimental data fitting the model and passing through the origin $[35,36]$. Table 3 contains a summary of these models with their mathematical expressions.

It is worth noting that most adsorption studies related to PW in this work reported kinetics being very well described by pseudo-second order model as illustrated in the following references: [37-39]. To state this decisively, studies compared the fit of pseudo-first/second order, Elovich or intraparticle diffusion models when applicable as shown in these examples: [40-43].

Table 3. Common kinetics models in PW.

\begin{tabular}{ccc}
\hline Model Name & Equation & Mechanism \\
\hline Pseudo-first order & $\frac{d q_{t}}{d t}=k_{1}\left(q_{e}-q_{t}\right)[44]$ & Physical adsorption \\
Pseudo-second order & $\frac{d q_{t}}{d t}=k_{2}\left(q_{e}-q_{t}\right)^{2}[45]$ & Chemisorption \\
Elovich & $\frac{d q_{t}}{d t}=\alpha \exp ^{-\beta q_{t}[34]}$ & Chemisorption \\
Intraparticle diffusion & $q_{t}=k_{i} t^{\frac{1}{2}}[36,46]$ & Intramolecular diffusion \\
\hline
\end{tabular}


Where $q_{e}$ is the equilibrium adsorbate adsorbed in $(m g / g), q_{t}$ is the amount of adsorbate at time $t$ and $k$ is the equilibrium rate constant of the model. $\alpha$ in the Elovich model is the initial rate of adsorbent and $\beta$ is the relationship to surface coverage extent and chemisorption activation energy.

\subsection{Isotherms}

The most frequent assessment observed in the investigations of adsorption systems is fitting the adsorption equilibrium data in terms of isotherm models. The equilibrium relationship between the adsorbent and the adsorbate are explained in the literature through various expressions. These equilibrium expressions are referred to as isotherms and they quantify the amount of solute adsorbed at a constant temperature $[47,48]$. To select a model that describes an adsorption system, experimental data are used to produce isotherm profiles. The isotherm model with the best fit is chosen as an equilibrium representation of the adsorption system [49]. The most commonly used isotherm models in the PW literature are Langmuir [50], Freundlich [51], Sips [52], Dubinin-Radushkevich [53] and Temkin [54] isotherms. Table 4 contains the mathematical expressions of these isotherm models.

Several studies discussed in this work either reported Langmuir [55] or Freundlich [56] isotherms to best fit their data, where some reported Temkin [57] or Dubinin-Radushkevich [58].

\subsubsection{Langmuir Isotherm}

As Langmuir isotherm is the most frequently used model in PW studies; it is one of the oldest empirical models that describe adsorption isotherms [47]. The formulation is based on four assumptions that are: (i) monolayer adsorption, (ii) adsorption occurs only at finite number of sites, (iii) all adsorption sites are equivalent and (iv) adsorbed solutes do not interact with each other [50,59].

\subsubsection{Freundlich Isotherm}

In addition to Langmuir isotherm, presented frequently in the PW literature is the Freundlich isotherm. The Fruendlich isotherm is the oldest known model that considers the non-ideality and reversibility of adsorption [60]. When this model is linearized, the slope of the expression is an indication of the adsorption intensity. The closer the slope of the model is to zero, the more heterogeneous is the surface of the adsorbent [61]. The assumptions for this model consist of (i) multilayer adsorption, (ii) non-uniform distribution of adsorption heat and affinity and (iii) heterogeneous surface $[51,60]$.

\subsubsection{Sips Isotherm}

With a frequent presence in the PW adsorption literature, the Sips model is an isotherm that combines the Langmuir and Freundlich models. These two models come into presence depending on the adsorbate concentration. At high adsorbate concentrations, the model predicts monolayer adsorption (Langmuir isotherm), where at low adsorbate concentrations, the model follows the Freundlich isotherm [52,62].

\subsubsection{Dubinin-Radushkevich Isotherm}

Using Gaussian energy distribution on heterogenous surfaces, the Dubinin-Radushevic isotherm is used to describe many PW adsorption systems in the literature. The adsorbent in this model follows a pore filling mechanism and it assumes the following: (i) multi-layer adsorption using Van Der Waal's forces, (ii) physical adsorption is taking place and (iii) microporous adsorbent $[53,63]$.

\subsubsection{Temkin Isotherm}

Frequently referred to in the PW literature is the Temkin equilibrium model. This model is based on the assumption that (i) all interacting dipoles at the surface are the same and (ii) adsorbate-adsorbate interaction exist at the surface such that a dipole interacts with a homogeneous electric field [54,59]. 
Table 4. Common isotherm models in PW.

\begin{tabular}{|c|c|c|}
\hline Isotherm Name & Equation & Parameters \\
\hline Langmuir & $q_{e}=\frac{Q_{o} b C_{e}}{1+b C_{e}}$ & $\begin{array}{l}q_{e}(m g / g) \text { is the amount of solute adsorbed, } \\
Q_{o}(m g / g) \text { is the maximum monolayer on the } \\
\text { adsorbent, } b(L / m g) \text { is the Langmuir isotherm } \\
\text { constant and } C_{e}(m g / L) \text { is the equilibrium } \\
\text { concentration }[50,59]\end{array}$ \\
\hline Freundlich & $q_{e}=K_{F} C_{e}^{\frac{1}{n}}$ & $\begin{array}{l}K_{F}(m g / g)(L / g)^{n} \text { is the Freundlich constant and } \frac{1}{n} \\
\text { the heterogeneity factor }[51,60]\end{array}$ \\
\hline Sips & $q_{e}=\frac{K_{s} C_{e}^{\beta_{s}}}{1-a_{s} C_{e}^{\prime \beta_{s}}}$ & $\begin{array}{l}\mathrm{Ks}\left(\mathrm{Lg}^{-1}\right) \text { is Sips isotherm constant, } \beta_{S} \text { is Sips } \\
\text { isotherm exponent and } a_{S}\left(\mathrm{Lg}^{-1}\right) \text { is Sips isotherm } \\
\text { model constant }[52,62]\end{array}$ \\
\hline Dubinin-Radushkevick & $q_{e}=q_{m} \exp ^{-\beta\left[R T \ln \left(1+\frac{1}{C_{e}}\right)\right]^{2}}$ & $\begin{array}{l}\beta\left(m o l^{2} / k J^{2}\right) \text { is the Dubinin-Radushlkevich } \\
\text { constant, } R \text { is the gas constant and } T \text { is the absolute } \\
\text { temperature }[53,63]\end{array}$ \\
\hline Temkin & $q_{e}=\frac{R T}{b_{T}} \ln \left(A_{T} C_{e}\right)$ & $\begin{array}{l}R \text { is the universal gas constant, } T \text { is the } \\
\text { absolute temperature, } b_{T}(\mathrm{Jg} / \mathrm{molmg}) \text { is the Temkin } \\
\text { isotherm constant and } A_{T}(\mathrm{~L} / \mathrm{mg}) \text { is the Temkin } \\
\text { isotherm equilibrium binding constant }[54,59]\end{array}$ \\
\hline
\end{tabular}

\section{Produced Water Adsorbents}

Different types of adsorbent materials have been used for the treatment of PW. These materials are often considered as natural (natural adsorbents) or synthetic (non-natural adsorbents) adsorbents [64]. The most common adsorbents that have been used for the treatment of contaminated water, especially produced water, are described in the following sections. Adsorbents derived from the Earth's crust and biological sources were categorized under the natural adsorbent sections. On the other hand, non-natural adsorbents included adsorbents synthesized in the lab or obtained by buying them from commercial entities. Figure 2 shows an overview of the different categories of adsorbents defined in this paper. It is important to note that biological adsorbents in this paper are those found from agricultural practices (trees and their derivatives) and the food chain waste. Tables 5 and 6 show a summary of the results reported for each discussed study in the sections below.

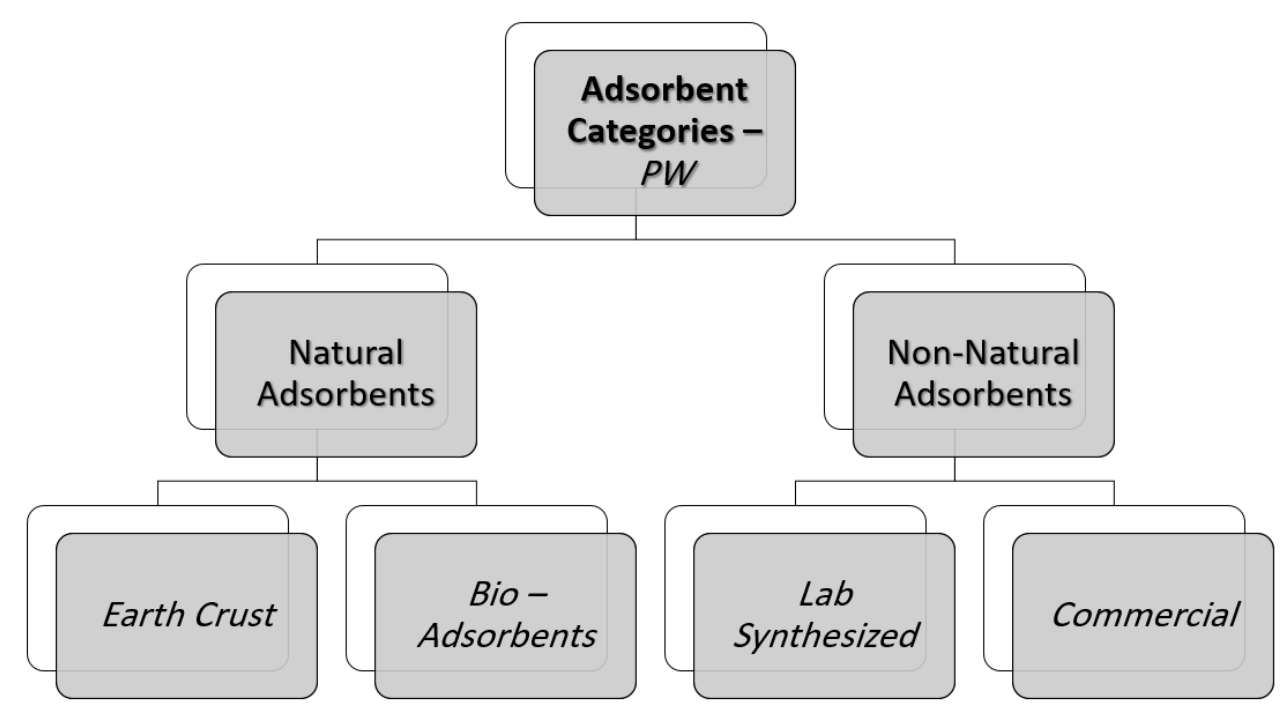

Figure 2. Classification of adsorbents. 


\subsection{Natural Adsorbents}

Adsorbents obtained through natural means were explored by a number of studies for the treatment of PW. Most of these studies reported better economics when compared to commercial adsorbents, making them more favorable. As mentioned earlier, natural adsorbents discussed in this section were materials either obtained from the Earth's crust or biological sources; agriculture (trees and their derivatives) or food wastes.

\section{Earth Crust Adsorbents}

Several researchers have studied the effectiveness of adsorbents that originated from the Earth's crust and mantle for PW treatment. Goethite $(\alpha \mathrm{FeO}(\mathrm{OH}))$, which is a naturally occurring compound present in the Earth's crust [65], was tested by Wainipee et al. for the removal of arsenate (As) in water with and without oil coating. The oil coating on the goethite was reported to not affect the kinetics of adsorption, while it halved the adsorption capacity. The study also mentioned that the surface area of goethite was the controlling variable in the adsorption process [37]. Similar to geothite, graphite is found in the Earth's mantle [66]. Exfoliated graphite from natural graphite was investigated by Takeuchi et al. as an adsorbent to remove oil in oil-water emulsions, where it is reported to have a good potential for PW treatment [67]. Graphene, which is a single layer of graphite [68], was also studied by Saleh et al. for the removal of antimony (III) metal from water. The graphene in this study was reported to adsorb the metal with high regeneration efficiency [69].

Like goethite, clay minerals (e.g., sepiolite, attapulgite [70], bentonite [71] and organoclay [72]) are also found on the Earth's crust [73]. These minerals were investigated by group of researchers for the adsorption of PW contaminants. Zheng et al. used sepiolite in their research for the removal of oil from water. The sepiolite adsorbent was modified in this study by two types of surfactants: (i) stearyl trimethyl ammonium bromide and (ii) dimethyl diotadecyl ammonium bromide. These surfactant modified adsorbents were reported to have high adsorption efficiency and follow a physical endothermic adsorption path [74]. Attapulgite was used by Sueyoshi et al. for the oil adsorption from PW. The study used petroluem sludge modification; however, the reported capacity was lower than commercial activated carbon [75]. The natural existence of benotnite was also examined by Okiel et al. for the adsorption of oil from emulsified water. The research showed independence of initial oil concentration from the adsorption process [76]. Emam et al. further investigated bentonite with organoclay modification for the adsorption of oil. Their results showed that the modification enhanced the adsorption efficiency and performed better than commercial activated carbon [77]. With clay minerals being part of natural dolomite formation [78], this sedimentary carbonate rock on the Earth's surface [79] was studied for heavy metals removal. As mentioned earlier, barium is a potential contaminant that is possible to exist in PW. Ghaemi et al. utilized dolomite powder for the removal of barium and strontium from aqueous solutions. This removal was reported to occur through exothermic adsorption with high dependance on the system's pH. The study also reported that dolomite is a potential inexpensive adsorbent for barium and strontium removal [80].

Clay adsorbents were also studied as a pre-treatment steps to various processes. These processes included membranes, direct air floatation (DAF) and co-agulation. The utilization of bentonite was further proved useful by Shahruddin et al., in which they used the adsorbent as a pre-treatment step to membranes. The presence of bentonite as a pre-step was reported to strengthen the structure of the membrane and enhanced its oil removal capacity [81]. Organoclay was also studied by Younker et al. as a pre-step to DAF. The targeted contaminants in this step were reported to vary between oil, naphthalene and phenol. The study compared adsorption-DAF to adsorption-coagulation integration, where the adsorption-DAF system was shown to have more significant removal [82]. Younker et al. also reported that organoclay has better affinity towards napthalene and phenol in saline water [83]. 


\subsection{Bio-Adsorbents}

In addition to earth-based adsorbents, Bio-adsorbents from biological sources were of interest to various researchers for the treatment of different types of industrial wastewater. The adsorbents were observed in the literature to be sourced from either agricultural practices or the food chain waste. From agricultural practices, Elsherif et al. [84] and Kunjirama et al. [43] groups investigated the usage of plant branches for the adsorption of heavy metals. As described earlier, heavy metals are potential contaminants of PW depending on the location its produced at. Elsherif et al. used olive branches as a source for obtaining activated carbon for the adsorption of lead, zinc, copper and cadmium from water. The study reported that $\mathrm{pH}$ was the most influential element on the olive branch adsorbent [43]. In terms of branches, also oil palm branches were examined by Kunjirama et al. for the adsorption of mercury and methyl mercury in water. The branches in the study were modified with an amine-containing ligand that enhanced the adsorption process. The study reported that oil palm branch-based adsorbent was stable for a number of regeneration cycles [43].

Agricultural adsorbents were also extended in recent studies from plant and branches to plant derivatives-fruits and their products. Araujo et al. used loberia fruit for the removal of lead from water. In their study, factorial design was used to reduce the number of experiments and they reported high adsorption efficiency for the fruit adsorbent [85]. Sueyoshi et al. also investigated date palm (fruit) for the adsorption of oil by preparing the adsorbent at $700{ }^{\circ} \mathrm{C}$ and $800{ }^{\circ} \mathrm{C}$. The obtained activated carbons at these temperatures were reported to have higher adsorption capacity than the commercial adsorbent. This higher efficiency was concluded in the study as a significant economic factor in comparison to commercial adsorbents, as the date palms were locally sourced [75]. Activated date-pit was also studied by El-Naas et al. for the treatment of refinery PW. The results in this study were reported in terms of chemical oxidation demand (COD), which is a method of describing the amount of organics in water [86]. The COD in the study showed that at low concentrations, adsorption was mass transfer dominant, where at higher COD it was intrinsically kinetic-dominant. The study also added the benefits of utilizing this date-pit adsorbent as it poses a promising disposal method for the date palm industry [41]. Similarly, El-Naas et al. utilized the activated date-pit for the removal of phenols from petroleum wastewater. The results for the phenol containing wastewater were reported for both synthetic and actual refinery PW, where the potentials of this adsorbent were further shown [87]. The date derivative; date seeds were also studied by Al Haddabi et al. for the removal of dissolved organic carbon (DOC) in PW. The date seeds were shown to adsorb more DOC with the increase of: (i) DOC initial concentration, (ii) contact time and (iii) date seed dosage. These seed adsorbents were recommended by the study as inexpensive adsorbents for PW treatment [55].

In addition to fruits, fruit peels (part of agricultural products), were observed to be part of the PW literature. El Nafaty et al. used banana peel as an adsorption medium for oil removal from PW. The peel adsorbent was reported to have its efficiency proportional to the system's alkalinity and temperature. The temperature effect was mentioned to occur until $60^{\circ} \mathrm{C}$ [88]. Ibrahim et al. also tested pomegranate peel for the removal of oil from PW. The results showed effectiveness of the peel adsorbent by removing the oil at low costs. This peel also exhibited good output with regeneration, as it remained stable throughout the process [89]. Along these peels, pineapple Peel biochars were investigated by Shakya et al. for the adsorption of chromium from water. The pineapple peel biochars in the study were prepared at temperatures ranging between $350{ }^{\circ} \mathrm{C}$ and $650{ }^{\circ} \mathrm{C}$. Out of this range, biochar at $350{ }^{\circ} \mathrm{C}$ showed the highest adsorption of chromium. This was reasoned by the polar functional groups on the biochar surface that decreased with the temperature increase [90].

Along plants and fruits, wooden residue from the agriculture was consistently investigated. Rice husks were studied by Song et al. [91] and Shen et al. [92] for the adsorption of metals from water. Song et al. modified the rice husks for the removal of mercury from water with: (i) sulfur and organosilane functionalization or (ii) sodium hydroxide $(\mathrm{NaOH})$ treatment. From the adsorption studies, it was reported that functionalized rice husks showed better adsorption capacity and stability with the regeneration cycles. The study concluded with the benefits of using these 
adsorbents due to their abundant availability and low cost [91]. Shen et al. also used rice husk to obtain biochars for the adsorption of nickel from PW. The biochars were produced at $550{ }^{\circ} \mathrm{C}$ and $700{ }^{\circ} \mathrm{C}$, where $700{ }^{\circ} \mathrm{C}$ biochars reported better adsorption. Similarly, wheat straw biochars were used in the study and showed superior performance to rice husk biochars for nickel removal [92]. The utilization of rice husks was also investigated for petroleum spills remediation by Kenes et al. The study reported the effectiveness of the rice husk adsorbent and reported its structure to be like that of amorphous $\mathrm{SiO}_{2}$ [93]. In terms of organic matter, biochar wheat straw was of interest to Shi et al. for the adsorption of dissolved organic matter from PW. The wheat straw biochar in the study was modified with chitosan at $700{ }^{\circ} \mathrm{C}$, in which it increased the adsorption capacity. This capacity increase was reasoned by the increased micropores caused by the addition of chitosan. The study recommended this chitosan modified adsorbent as a cheap adsorbent for dissolved organic matter removal [94].

With cadmium being a potential contaminant in PW, a number of researchers used wooden residue for cadmium metal removal from water. Li et al. used rape straw to produce a biochar with modification for cadmium removal. The modification for testing was either with: (i) alkaline treatment with $\mathrm{NaOH}$, (ii) $\mathrm{MnO}_{4}$ impregnation or (iii) magentic treatment with $\mathrm{FeCl}_{3}$. Out of these modifications, the $\mathrm{MnO}_{4}$ impregnation showed superior results in terms of adsorption. This was reasoned by the increased micropore size, increased surface area and modified pore structure [95]. Cadmium removal from water was also investigated using corn straw by Chi et al. The corn straw was used to obtain biochar at $400{ }^{\circ} \mathrm{C}$, where it showed a good affinity towards the cadmium metal. It is worth mentioning that the study also reported the same for lead [96]. Another study by Peng at al. considered sawdust biochar for the adsorption of cadmium. The sawdust was modified with phosphoric acid, in which it reported an increase in capacity. Similar results were also reported for copper [97].

For hydrocarbon removal from PW, a number of investigations varied the pore sizes of wooden adsorbents in their studies. Different pore sizes were examined in a study by Iranmanesh et al. using sawdust for the removal of naphthenic acid. The sawdust in the study was used as a source for activated carbon preparation at different pore sizes. The pore size variation was based on physical or chemical activation, where the chemical activation showed better adsorption. This was reasoned by the greater surface area of the adsorbent [98]. Behnood et al. investigated sugarcane at different mesh sizes for the removal of oil from PW. This study reported improved oil adsorption when particle size was decreased. Like Iranmanesh et al., this was attributed by the increased surface area and homogeneity of the particles with size [99]. Likewise, this pattern was reported with organic compounds removal from water using Wood biochar. Caprariis et al. prepared biochars in a study in three variations: (i) at $550{ }^{\circ} \mathrm{C}$, (ii) at $750{ }^{\circ} \mathrm{C}$ and (iii) with $\mathrm{NaOH}$ and $750{ }^{\circ} \mathrm{C}$. From these preparations, the biochar at high temperature showed higher adsorption. This was reasoned by the increased surface area, which was further enhanced by the $\mathrm{NaOH}$ treatment [56].

As plants, fruits and wood residue are part of the food chain, food wastes were examined in recent PW studies. Chitosan as a food residue derived from shrimp shells [100] was used by Grem et al. to produce polymeric resins. These resins were used for the removal of oil from PW in a column study. The reported results in the study stated that higher adsorption were obtained at lower flow rates [101]. Hosny et al. also used chitosan with a coagulant and reported an enhanced adsorption for oil removal with the chitosan addition. This enhancement was mentioned to lower the economic costs of PW treatment [102]. The removal of oil was also studied by Misau et al. using raw eggshells that completely removed oil. The study in return concluded that it is a cheaper method to utilize raw material for the treatment of PW [103]. Pecan shell activated carbon was examined by Kaveeshwar et al. to adsorb iron(II) from fracking water. The iron adsorbate was reported to be removed at high levels and adsorption increased with temperature increase from $30^{\circ} \mathrm{C}$ to $70{ }^{\circ} \mathrm{C}$ [57]. Being part of PW contaminants, heavy metals adsorption from water were investigated by Alqadami et al. using camel bones nanocomposite. The metals considered in the study for adsorption were lead, cadmium and cobalt in water. This adsorption system was reported to be a novel approach for heavy metals removal as it presented effective adsorption [104]. 


\subsection{Non-Natural Adsorbents}

As described earlier, the literature contains a number of studies that investigates non-natural adsorbents for PW treatment. The below studies that are based on adsorbents synthesized in the lab or obtained commercially.

\subsubsection{Lab Synthesized Adsorbents}

Lab synthesized adsorbents in this paper were defined as emerging adsorbents that were obtained through a series of lab experiments for the purpose of treating PW. A group of studies were observed recently to use industrial wastes for PW treatment. El-Sayed et al. studied the usage of deposited carbon (waste) from a diesel engine for the removal of oil. These deposits were shown to have an independence from initial oil concentration. Furthermore, the adsorbed oil increased with the increase of carbon deposit dosage. The study concluded that carbon deposits are cheaper alternatives to activated carbon for oil removal [76]. In addition to oil, Yuan et al. used porous carbons (waste) activated with potassium hydroxide for the adsorption of a mixture of polycyclic aromatic hydrocarbons (PAHs). The source of the porous carbon in the study was from petroleum coke obtained during bitumen upgrading process. This porous medium was studied against five PAHs, which were: naphthalene fluorene, phenanthrene, pyrene and fluoranthene in water. For these PAHs, it was reported that competitive adsorption was improbable, where the adsorption capacity followed this order: naphthalene $\rightarrow$ fluorene $\rightarrow$ phenanthrene $\rightarrow$ pyrene. The investigation revealed that these PAHs were controlled by a two-stage diffusive transport with the first stage being faster than the second [105]. Potassium hydroxide porous carbon was also studied by Asenjo et al. for the removal of benzene and toluene from wastewater. This carbon was derived from carbon-tar and it was reported to contain a microporous and mesoporous pore structure. This combination of pore structures in the carbon adsorbent was reported to be behind the exhibited high kinetics. These kinetics were emphasized to be outstanding in comparison to porous material in the literature, due to adsorption occurring in its mesopores [106]. Sewage sludge was also used by Bjorklund et al. to produce activated carbon and target hydrophobic organic carbon. The results shown in the study by the sewage sludge activated carbon were comparable to the commercial one in terms of capacity. Based on this, the study stated that this adsorption capacity is a cost-effective usage of waste products [107]. Humic acid removal from PW was studied by An et al. using coal fly-ash as an adsorbent. The study examined the modification of coal fly-ash with acid using a microwave-assisted method and $\mathrm{pH}$ effect. The results showed that the modification enhanced the adsorption capacity and fly-ash is dependent on the $\mathrm{pH}$ of the system [108]. In addition to hydrocarbon contaminants, heavy metals were examined by Jung et al. using mill stone powder. The study used the stone powder for the removal of lead and arsenic. This investigation also modified the stone powder with a chitosan coating to study the effect on the adsorption capacity with these metals. The outcome of this study showed that adsorption successfully occurred, where the chitosan coating increased the adsorption capacity with lead and decreased it with arsenic [109].

In addition to using wastes as potential adsorbents, novel lab synthesized adsorbents were also studied by group of researchers for PW treatment. Abdel-Shafy et al. synthesized a novel resin using gamma rays for the removal of oil. The resin was prepared by mixing phenyl epoxy, poly vinyl pyrrolidone and $\mathrm{Fe}_{3} \mathrm{O}_{4}$ together. The adsorption process in the study was followed by a microfilteration step which was reported to accomplish complete removal of oil [110]. Ordered mesoporous carbon was utilized by Konggidinata et al. to remove benzene, toluene, ethylbenzene and xylenes (BTEX) from water. The experimental data showed that ordered mesoporous carbon has great affinity towards the adsorbates by this order: xylenes $\rightarrow$ ethylbenzene $\rightarrow$ toluene $\rightarrow$ benzene. Moreover, the thermodynamic study for these adsorbates reported that adsorption was endothermic, physical and spontaneous [111]. The removal of lithium metal was studied by Jang et al. using titanium based adsorbent. Lithium in the study was reported to show high selectivity with the tested adsorbent when a $\mathrm{pH}$ buffer was used [112]. 
Nanotechnology based adsorbents were also observed to be greatly part of lab synthesized adsorbents in PW. The various revelations seen since the introduction of nanotechnology are countless [113] as their wide usage is mainly based on their particle size of approximately $100 \mathrm{~nm}$ [114]. In recent PW adsorption research, nanoparticles were investigated using various materials for oil removal. Cortes et al. used silica based nanoparticles for the removal of oil from PW. These nanoparticles were modified with petroleum vacuum residue, where they were studied in saline and fresh water. The study reported that all the studied adsorbents (with and without modification) showed complete oil removal, but at different time durations. The time variations were reported to be related to the type of water and functionalization, where saline and functionalized systems exhibited shorter time [42]. Alumina nanoparticles were also investigated by Franco and Cortes et al. for the removal of oil from PW. The study was conducted in a similar manner to silica, where petroleum vacuum residue was used and it reported the same behaviour. However, the statement of this study was that alumina nanoparticles have greater affinity towards oil. This was reasoned by the polarity of silica nanoparticles [38]. Fard et al. used lab synthesized carbon nanotubes for the removal of oil by iron oxide functionlization [39] and also compared it with commercial carbon nanotube in another study [115]. The iron oxide modification study reported higher oil removal than unmodified carbon nanotubes [39], where the lab synthesized carbon nanotubes showed superior capacity to commercial ones [115]. Masooleh et al. investigated the usage of modified nanoparticles originating from organoclay (nanoclay) for the removal of petroleum hydrocarbons in water. The nanoclay in this study was modified through exchanging sodium ions by hexadecyltrimethylammoinium bromide in montmorillonite structure. This nanoclay was tested against hydrocarbons ranging from crude oil, kerosene, gasoline and toluene that stimulated oily wastewater. The study showed that the modified nanoclay exhibited nearly higher adsorption capacity than the unmodified one [116].

Similar to other studies, lab synthesized nanoparticles were also examined for the removal of heavy metals as they are potential PW contaminants. Fard et al. examined the usage of MXene nanosheet by obtaining it from titanium(III) carbide (II) for the adsorption of barium from PW. These nanosheets were reported to show superior adsorption capacities to other commercial adsorbents. In addition to this, great affinity towards barium in a multi-metal solution was also reported by the Mxene nanosheets [117]. Cupric oxide nanoparticles were also researched with heavy metals by Reddy et al. for the removal of As from water. These nanoparticles were shown to be more effective in adsorption after desorption. This was reasoned by the surface area renewal for reaction after nanoparticle's regenration. Using cupric oxide for water treatment was stated by the study to potentially require a simple process [118]. Yen et al. investigated heavy metals removal using dendrimer modified magnetic nanoparticles. The heavy metals considered in this study were palladium, gold and silver. The affinity and stability of the dendrimer was shown in the study by the adsorption and regeneration results. However, it was reported that further dendrimer modification with acid did not enhance this adsorption [119].

\subsubsection{Commercial Adsorbents}

Non-natural adsorbents such as the commercially available ones were also investigated for the treatment of PW. Belbase et al. [120] and Ma et al. [121] used zeolite as an adsorbent for the removal of sodium cation $\left(\mathrm{Na}^{+}\right)$and toluene respectively. For the $\mathrm{Na}^{+}$study, $\mathrm{PW}$ from coalbed natural showed that $\mathrm{Na}^{+}$adsorption was dependent on the zeolite size. This dependence was reported to be inversely proportional, as adsorption occured more in smaller sized particles. The adsorption was also examined in a field site to evaluate the usefulness of zeolites. This test reported that treated PW lowered the damage caused to the soil by $\mathrm{Na}^{+}$ions [120]. In the toluene study, the investigation was conducted in a column and batch experiments. The study reported that column experiments showed higher adsorption capacity with zeolite being stable throughout desorption. It is worth mentioning that the zeolite in Ma et al. study was coated with diphenyldichlorosilane [121]. Modified mesoporous organosilica commercial adsorbent was studied by Moura et al. for the removal of aromatic compounds, 
namely benzene, toluene, o-xylene and p-xylene (BTX). The BTX were reported to be adsorbed by Van der Waals forces onto the surface of organosilica material. Furthermore, characterization of the organosilica indicated that it consisted of a hexagonal structure of mesopores. These pores were reported to be operable at temperatures as high as $340{ }^{\circ} \mathrm{C}$ [40]. Albatrni et al. investigated four different commercial synthetic resins for the adsorption of oil in PW. The resins in the study were: (i) Optipore L493, (ii) Amberlite IRA 958, (iii) Amberlite XAD 7 and (iv) Lewatit AF 5. These commercial resisns were shown to be independent of $\mathrm{pH}$ and have a great affinity towards oil. Out of the four adsorbents, Amberlite XAD 7 was reported to have the fastest kinetics, where Lewatit AF 5 showed highest adsorption capacity [58].

Commercial activated carbon was mentioned variously in a number of studies related to PW. Most of these investigations used activated carbon as an adsorption capacity benchmark. In terms of clay studies, commercial activated carbon was compared to attapulgite, organoclay and bentonite. The outcome of the comparison with attapulgite reported that activated carbon had a higher surface area that resulted in a greater adsorption capacity for oil [75]. With organoclay, the adsorption of naphthalene and phenols were also reported to be superior in activated carbon [82]. On the other hand, with bentonite, activated carbon showed lower capacity for oil, making bentonite more favorable [77]. A different study compared commercial activated carbon with sawdust based activated carbons. These sawdust based activated carbons were reported to have a better capacity for naphthenic acid removal [98]. Biochar performance was also compared to activated carbon and showed 2.5 greater adsorption capacity for organic compounds removal [56]. On the other hand, a study examined the effectiveness of commercial activated carbon for the removal of hydrocarbons and polyethylene glycols from hydraulic fracturing PW. The results showed high adsorption capacities that were enhanced by adding a coagulant [122]. In a column study, El-Naas et al. studied the adsorption of phenols using activated carbon. The activated carbon packed bed in this study was reported to be highly dependent on: (i) feed concentration, (ii) flow rate and (iii) amount of packing. Additionally, the study also showcased a simple empirical formula to model the system and was reported to be based on the Langmuir affinity parameter [123]. El-Naas et al also reported that this adsorbent is a potential inexpensive alternative to commercial activated carbon [41,87]. 
Table 5. Natural adsorbents discussed in this review.

\begin{tabular}{|c|c|c|c|}
\hline Material & Target & Adsorption Capacity & Reference \\
\hline Attapulgite & oil & 155 mg-oil/g-adsorbent & [75] \\
\hline Attapulgite with petroleum sludge & oil & 405 mg-oil/g-adsorbent & [75] \\
\hline Date palm $\left(700^{\circ} \mathrm{C}\right)$ & oil & $1330 \mathrm{mg}$-oil/g-adsorbent & [75] \\
\hline Date palm $\left(800^{\circ} \mathrm{C}\right)$ & oil & $1425 \mathrm{mg}$-oil/g-adsorbent & [75] \\
\hline Organoclay & oil & $100 \mathrm{mg}$ oil $/ \mathrm{L}$ to $15 \mathrm{mg} / \mathrm{L}$ & [82] \\
\hline Organoclay & naphthalene & $1 \mathrm{mg}$ napthalene/L to $0.11 \mathrm{mg}$ naphthalene/L & [82] \\
\hline Organoclay & phenol & none & [82] \\
\hline Organoclay & oil & $100 \mathrm{mg}$ oil $/ \mathrm{L}$ to $7 \mathrm{mg} / \mathrm{L}$ & [82] \\
\hline Organoclay & naphthalene & $1 \mathrm{mg}$ napthalene/ $\mathrm{L}$ to $0.11 \mathrm{mg}$ naphthalene/L & [82] \\
\hline Sugarcane & oil & $6.6 \mathrm{~g}$ oil $/ \mathrm{g}$ adsorbent & [99] \\
\hline Chitosan Microspheres & oil & $>90 \%$ removal & [101] \\
\hline Chitosan & oil & $96.35 \%$ removal & [102] \\
\hline Chitosan & oil & $99 \%$ removal & [102] \\
\hline Chitosan & oil & $85 \%$ removal & [102] \\
\hline Chitosan & Dissolved Organic Matter & $52 \%$ removal & {$[94]$} \\
\hline Wheat Straw & Dissolved Organic Matter & $12 \%$ removal & [94] \\
\hline zeolite & Toluene & $16.58 \mathrm{mg}$-toluene/g-adsorbent & {$[121]$} \\
\hline Bentonite & oil & $96.5 \%$ removal & [76] \\
\hline Bentonite & oil & 38.5 mg-hydrocarbon/g adsorbent & [77] \\
\hline org-bentonite & oil & 48 mg-hydrocarbon/g adsorbent & [77] \\
\hline Commercial Organoclay & Napthalene in freshwater & $13.76 \mathrm{~L} / \mathrm{g}$ & [83] \\
\hline Organoclay & Napthalene in freshwater & $16.42 \mathrm{~L} / \mathrm{g}$ & [83] \\
\hline Commercial Organoclay & Napthalene in saline water & $4.61 \mathrm{~L} / \mathrm{g}$ & [83] \\
\hline Organoclay & Napthalene in saline water & $14.17 \mathrm{~L} / \mathrm{g}$ & [83] \\
\hline Commercial Organoclay & Napthalene in oil water & $28 \mathrm{~L} / \mathrm{g}$ & [83] \\
\hline Organoclay & Napthalene in oil water & $29.39 \mathrm{~L} / \mathrm{g}$ & [83] \\
\hline Commercial Organoclay & Phenol in freshwater & $0.08 \mathrm{~L} / \mathrm{g}$ & [83] \\
\hline Organoclay & Phenol in freshwater & $1.01 \mathrm{~L} / \mathrm{g}$ & [83] \\
\hline Commercial Organoclay & Phenol in saline water & $0.09 \mathrm{~L} / \mathrm{g}$ & [83] \\
\hline Organoclay & Phenol in saline water & $2.25 \mathrm{~L} / \mathrm{g}$ & [83] \\
\hline Commercial Organoclay & Phenol in oil water & $0.1 \mathrm{~L} / \mathrm{g}$ & [83] \\
\hline Organoclay & Phenol in oil water & $1.74 \mathrm{~L} / \mathrm{g}$ & [83] \\
\hline Rice Husks & Nickel & $98 \%$ removal & [92] \\
\hline Sepiolite & oil & 1013.5 mg-oil/g-adsorbent (>99\% removal) & [74] \\
\hline Sepiolite & oil & $958 \mathrm{mg}$-oil/g-adsorbent (>99\% removal) & [74] \\
\hline
\end{tabular}


Table 5. Cont

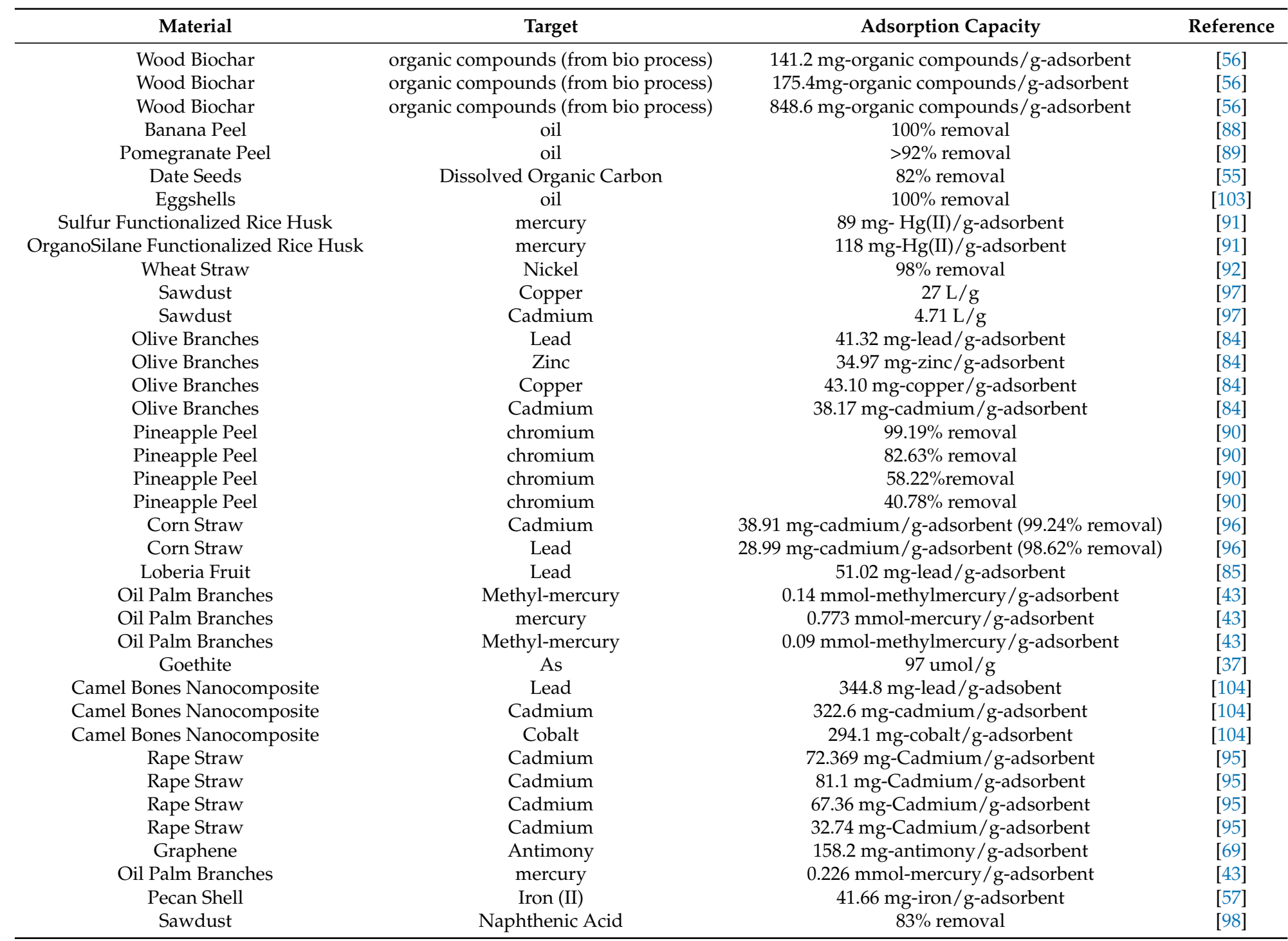


Table 6. Non-Natural adsorbents discussed in this review

\begin{tabular}{|c|c|c|c|}
\hline Material & Target & Adsorption Capacity & Reference \\
\hline Commcercial Activated Carbon & oil & $730 \mathrm{mg}$-oil/g-adsorbent & [75] \\
\hline Exfoliated Graphite & oil & from $100 \mathrm{mg}$-oil/L to $0.1 \mathrm{mg}$-oil/L & [67] \\
\hline Activated Carbon & Polyethylene glycols & $99.60 \%$ & [122] \\
\hline Activated Carbon & total petroleum hydrocarbons & $92 \%$ removal & [122] \\
\hline Activated Carbon & total petroleum hydrocarbons & $99 \%$ removal & [122] \\
\hline phenyl epoxy/poly (vinyl pyrrolidone) $/ \mathrm{Fe}_{3} \mathrm{O}_{4}$ & Oil & $99.9 \%$ removal & [110] \\
\hline Functionalized Silica Nanoparticles ( $4 \%$ VR) & oil saltwater & $100 \%$ removal & [42] \\
\hline Functionalized Silica Nanoparticles ( $2 \%$ VR) & oil saltwater & $100 \%$ removal & [42] \\
\hline Silica Nanoparticles & oil saltwater & $93 \%$ removal & [42] \\
\hline Functionalized Silica Nanoparticles ( $2 \%$ VR) & oil freshwater & $100 \%$ removal & [42] \\
\hline Functionalized Silica Nanoparticles ( $4 \%$ VR) & oil freshwater & $100 \%$ removal & [42] \\
\hline Alumina Nanoparticles & oil saltwater & $185.76 \mathrm{mg}$-oil $/ \mathrm{g}$ adsorbent & {$[38]$} \\
\hline Functionalized Alumina Nanoparticles ( $4 \%$ VR) & oil saltwater & $188.64 \mathrm{mg}$-oil/g-adsorbent & [38] \\
\hline Functionalized Alumina Nanoparticles ( $2 \%$ VR) & oil saltwater & $193.77 \mathrm{mg}$-oil/g-adsorbent & [38] \\
\hline Lewatit AF 5 & oil & $>98 \%$ removal & [58] \\
\hline Deposited Carbon & oil & $97.5 \%$ removal & [76] \\
\hline Powder Activted Carbon & oil & $82.6 \%$ removal & [76] \\
\hline Activated Carbon & oil & $30 \mathrm{mg}$-hydrocarbon/g adsorbent & [77] \\
\hline Acidic Modified Activated Carbon & oil & $40 \mathrm{mg}$-hydrocarbon/g adsorbent & [77] \\
\hline Carbon Nanotubes & oil & $87 \%$ removal & [39] \\
\hline Carbon Nanotubes & oil & $98.52 \%$ removal & [39] \\
\hline Carbon Nanotubes & oil & $87 \%$ removal & [115] \\
\hline Produced-Carbon Nanotubes & oil & $97 \%$ removal & [115] \\
\hline Amberlite XAD 7 & oil & $>98 \%$ removal & [58] \\
\hline optipore L493, & oil & $>98 \%$ removal & [58] \\
\hline Silica Nanoparticles & oil freshwater & $93 \%$ removal & [42] \\
\hline Sewage Sludge & hydrophobic organic compounds (HOC) & 2800 mico gram-HOC/g-adsorbent & [107] \\
\hline Ordered Mesoporous Carbon & Benzene & $5.1 \mathrm{mg}$-benzene/g-adsorbent & [111] \\
\hline Ordered Mesoporous Carbon & Toluene & $18.2 \mathrm{mg}$-benzene/g-adsorbent & [111] \\
\hline Ordered Mesoporous Carbon & Ethylbenzene & $31.7 \mathrm{mg}$-benzene/g-adsorbent & [111] \\
\hline Ordered Mesoporous Carbon & xylene & 46 mg-benzene/g-adsorbent & [111] \\
\hline Activated carbon & organic compounds (from bio process) & 318 mg-organic compounds/g-adsorbent & [56] \\
\hline Organosilica & Benzene & $40 \%$ removal & [40] \\
\hline Organosilica & $\mathrm{o}$-xylene & $>60 \%$ removal & [40] \\
\hline Organosilica & p-xylene & $>60 \%$ removal & [40] \\
\hline Organosilica & Toluene & $>60 \%$ removal & {$[40]$} \\
\hline Amberlite IRA 958 & oil & $<25 \%$ removal & [58] \\
\hline Titanium-based Adsorbent & Lithium & $92.7 \%$ removal & [112] \\
\hline CuO Nanoparticles & Arsenic & $99 \%$ removal & [118] \\
\hline Dendrimer Magnetic Nanoparticles & Palladium & $3.6 \mathrm{mg}-\mathrm{Pd}(\mathrm{IV}) / \mathrm{g}$-adsorbent & [119] \\
\hline Dendrimer Magnetic Nanoparticles & Gold & $3.58 \mathrm{mg}$-gold/g-adsorbent & [119] \\
\hline Dendrimer Magnetic Nanoparticles & Silver & $2.84 \mathrm{mg}$-silver/g-adsorbent & [119] \\
\hline Coal Fly-Ash waste & Sulfonated Humic Acid & $92.83 \%$ removal & [108] \\
\hline MXene Nanosheets & Barium & $100 \%$ removal & [117] \\
\hline Zeolite & $\mathrm{Na}^{+}$ & $21 \mathrm{Na}^{+} \mathrm{g} / \mathrm{kg}$ zeolite (bicarbonate) $18 \mathrm{Na}^{+} \mathrm{g} / \mathrm{kg}$ zeolite (chloride) & {$[120]$} \\
\hline
\end{tabular}




\section{Summary and Future Perspective}

The discharge of PW is undeniably foreseen to increase in the near future, hence there is a need for an economic path of treatment. Introducing this path of treatment will incentivize treated PW in the industry for reuse. To serve this purpose, this review gathers recent research on PW adsorption to showcase the current level of studies performed. From the established studies, it can be concluded that there has been a vast focus on natural adsorbents (Figure 3). This was reasoned by multiple studies to be based on their inexpensive economic potential. However, to decisively make this conclusion, it is recommended to explore each adsorbent in terms of essential factors related to their usage. Such factors should encompass the adsorbent's potential by reporting their availability, processing, environmental and economical aspects in more details. Addressing these factors when evaluating an adsorbent system will aid in establishing the adsorbent/contaminant fates. Knowing the fate of a treatment system is of a great value, as it gives a better image about the adsorbent's potential.

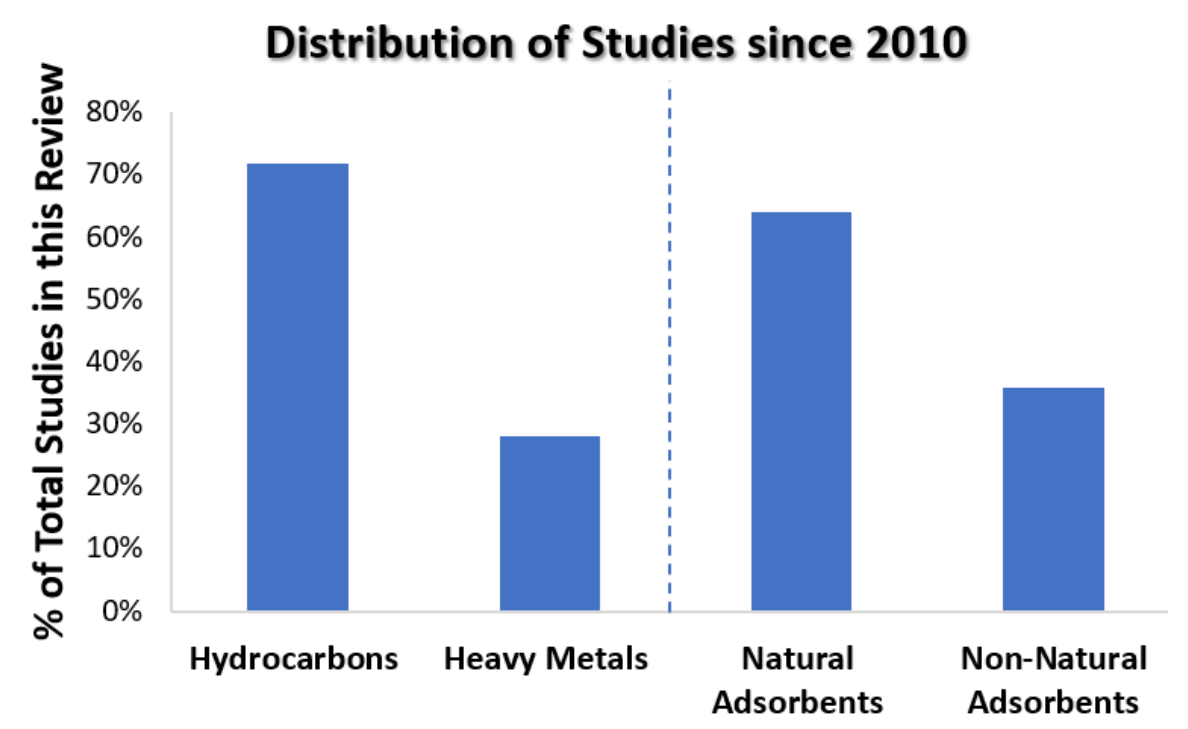

Figure 3. Distribution of recent adsorption studies, since 2010. The left hand side shows the portion of adsorbent studies that targeted hydrocarbons or heavy metals, where the right hand side is the portion of studies that utilized natural or non-natural adsorbents.

In addition to gaining an insight into the adsorbent's potential, a consistent metric is needed for describing the performance of an adsorbent system. As most discussed adsorbent systems in this work showed good adsorption attributes, a distinct comparison was difficult to achieve. This is due to the inconsistency of data presentation in the studies covered. To resolve this issue, it is recommended to develop a metric for how these adsorption data should be showcased. Moreover, up-to-date these adsorbents stand to be constrained to lab-scale findings (batch experiments). The available adsorbent literature for PW treatment needs to evolve to continuous experimentations and modeling stages. In terms of continuous experiments limited work was observed in the literature, where for modeling it is close to none. With regards to continuous studies, a number of researchers conducted column studies using polymeric resins [101], zeolite [121] and commercial activated carbon [123]. The output from these studies has shown how significant are the operational parameters of a column and how they differ from batch work. Conducting more work in similar a manner alongside modeling and design is expected to make the transition to pilot scale investigations smoother. This is as well as it will aid in reporting findings related to large-scale column operations. Once all these research stages are saturated—continuous, modeling and pilot scale—an implementation of these findings can be made in operations taking place in the oil and gas industry. The transition towards these large-scale operations is recommended to be mainly done while always considering three different aspects when 
conducting research, namely: (i) PW discharge regulatory level (ii) optimization, (iii) scale-up factors and (iv) process maintenance. Successfully achieving these in the PW adsorption research will aid researchers in better showcasing the potential of their adsorbents.

This review was aimed to mainly showcase hydrocarbon and heavy metal contaminants in PW and that is to promote the transition towards scale up studies. In terms of studies distribution, there is more focus on hydrocarbons than heavy metals. Furthermore, the investigations conducted were mainly reporting the adsorbent isotherms and adsorption capacity. These investigations also showed a trend of lacking kinetic studies. Moving forward, with a focus on contaminants' uptake, kinetic studies should be part of the reported parameters. These parameters add a value in adsorbent system modeling and scale-up as kinetics play a role when devising a model. Furthermore, for a system to be modelled properly, actual PW simulation is needed. This can be done by studying multiple PW contaminants in a single system. This to ensure that the reported parameters will not differ greatly as shown in El-Naas et al. [87] if actual PW is used. Ensuring this will better show the potential of the proposed adsorbent as actual PW consist of multiple contaminants and changes in concentration during operation. With regards to PW adsorbent source, -as stated earlier- it is difficult to make a decisive comparison between the adsorbents as most studies report good adsorption according to their own metrics. This by default makes the discussed three adsorbent types in this work comparable in terms of adsorption performance. However, when considering the overall potential of these adsorbents, natural adsorbents are the ones that stand out the most due to their economic advantage. With this, we cautiously recommend natural adsorbents when considering PW treatment, as this type exhibits an economic potential and introduces a pathway for waste management.

Author Contributions: Conceptualization, H.Q.; methodology, R.Y.; formal analysis, R.Y.; investigation, R.Y.; writing - original draft preparation, R.Y.; writing - review and editing, H.Q. and M.H.E.-N.; visualization, R.Y.; supervision, H.Q. and M.H.E.-N.; funding acquisition, R.Y. and H.Q. All authors have read and agreed to the published version of the manuscript.

Funding: This publication was made possible by GSRA grant, ID\# GSRA5-1-0531-18104, from the Qatar National Research Fund (a member of Qatar Foundation), Open Access funding provided by the Qatar National Library.

Conflicts of Interest: The authors declare no conflict of interest.

\section{References}

1. Veil, J.A. Produced Water Management Options and Technologies. In Produced Water: Environmental Risks and Advances in Mitigation Technologies; Springer: New York, NY, USA, 2011; pp. 537-571. [CrossRef]

2. Hansen, B.R.; Davies, S.R. Review of potential technologies for the removal of dissolved components from produced water. Chem. Eng. Res. Des. 1994, 72, 176-188.

3. Abdalla, M.; Nasser, M.; Kayvani Fard, A.; Qiblawey, H.; Benamor, A.; Judd, S. Impact of combined oil-in-water emulsions and particulate suspensions on ceramic membrane fouling and permeability recovery. Sep. Purif. Technol. 2019, 212, 215-222. [CrossRef]

4. Zsirai, T.; Qiblawey, H.; Buzatu, P.; Al-Marri, M.; Judd, S. Cleaning of ceramic membranes for produced water filtration. J. Pet. Sci. Eng. 2018, 166, 283-289. [CrossRef]

5. Guerra, K.; Dahm, K.; Dundorf, S. Oil and Gas Produced Water Management and Beneficial Use in the Western United States; Science and Technology Program Report; US Department of the Interior, Bureau of Reclamation Denver: Denver, CO, USA, 2011.

6. Zhong, J.; Sun, X.; Wang, C. Treatment of oily wastewater produced from refinery processes using flocculation and ceramic membrane filtration. Sep. Purif. Technol. 2003, 32, 93-98. [CrossRef]

7. Chakrabarty, B.; Ghoshal, A.; Purkait, M. Cross-flow ultrafiltration of stable oil-in-water emulsion using polysulfone membranes. Chem. Eng. J. 2010, 165, 447-456. [CrossRef]

8. Zsirai, T.; Al-Jaml, A.K.; Qiblawey, H.; Al-Marri, M.; Ahmed, A.; Bach, S.; Watson, S.; Judd, S. Ceramic membrane filtration of produced water: Impact of membrane module. J. Sep. Purif. Technol. 2016, 165. [CrossRef] 
9. Weschenfelder, S.E.; Louvisse, A.M.; Borges, C.P.; Meabe, E.; Izquierdo, J.; Campos, J.C. Evaluation of ceramic membranes for oilfield produced water treatment aiming reinjection in offshore units. J. Pet. Sci. Eng. 2015, 131, 51-57. [CrossRef]

10. Ebrahimi, M.; Willershausen, D.; Ashaghi, K.S.; Engel, L.; Placido, L.; Mund, P.; Bolduan, P.; Czermak, P. Investigations on the use of different ceramic membranes for efficient oil-field produced water treatment. Desalination 2010, 250, 991-996. [CrossRef]

11. Veil, J.; Puder, M.; Elcock, D.; Redweik, R.J., Jr. A White Paper Describing Produced Water from Production of Crude Oil, Natural Gas, and Coal Bed Methane; Prepared by Argonne National Laboratory; Department of Energy, National Energy Technology Laboratory: Lemont, IL, USA, 2004. [CrossRef]

12. Judd, S.; Qiblawey, H.; Al-Marri, M.; Clarkin, C.; Watson, S.; Ahmed, A.; Bach, S. The size and performance of offshore produced water oil-removal technologies for reinjection. Sep. Purif. Technol. 2014, 134, 241-246. [CrossRef]

13. Suez in the UK Zero Liquid Discharge. Available online: https://www.suez.co.uk/en-gb/ouroffering/businesses / what-are-you-looking-for/water-management/equipment-and-systems/zeroliquid-discharge-and-thermal-products (accessed on 15 February 2020).

14. Norwegian Petroleum Discharges to the Sea. Available online: https://www.norskpetroleum.no/en/ environment-and-technology / discharges-to-the-sea /\#: :text=Norway $\% 20$ established $\% 20 a \% 20$ zero $\%$ 2Ddischarge,been $\% 20$ achieved $\% 20$ for $\% 20$ chemical $\% 20$ additives.\&text=Chemicals $\% 20$ that $\% 20$ are $\%$ 20not $\% 20$ discharged, are\%20treated\%20as\%20hazardous\%20waste. (accessed on 15 February 2020).

15. AlBatrni, H. Novel Adsorbents for the Removal of Oil from Produced Water. Ph.D. Thesis, Qatar University, Al-Dafna, Qatar, 2019.

16. NPDES Compliance Inspection Manual; EPA: Washington, DC, USA, 2004.

17. Mohr, K. An Overview of US and International Regulations Regarding Hydrocarbons in Water Effluents. Proc. Water Environ. Fed. 2000, 2000, 158-166. [CrossRef]

18. Pedenaud, P. TOTAL Experience to Reduce Discharge of Hydrocarbons Through Produced Water. In Proceedings of the SPE International Health, Safety Environment Conference, Abu Dhabi, UAE, 2-4 April 2006. [CrossRef]

19. IEA. World Energy Outlook; IEA: Paris, France, 2019. [CrossRef]

20. Jiménez, S.; Micó, M.; Arnaldos, M.; Medina, F.; Contreras, S. State of the art of produced water treatment. Chemosphere 2018, 192, 186-208. [CrossRef] [PubMed]

21. Arthur, J.D.; Langhus, B.G.; Patel, C. Technical Summary of Oil and Gas Produced Water Treatment Technologies; EPA: Washington, DC, USA, 2005.

22. Lenntech. Chemical Properties of Barium. Available online: https://www.lenntech.com/periodic/elements/ ba.htm (accessed on 15 July 2020).

23. Hardi, M.; Siregar, Y.I.; Anita, S.; Ilza, M. Determination of heavy metals concentration in produced water of oil field exploration in siak regency. J. Phys. Conf. Ser. 2019, 1156, 012009. [CrossRef]

24. Qaiser, M.S.H.; Ahmad, I.; Ahmad, S.R.; Afzal, M.; Qayyum, A. Assessing Heavy Metal Contamination in Oil and Gas Well Drilling Waste and Soil in Pakistan. Pol. J. Environ. Stud. 2019, 28, 785-793. [CrossRef]

25. Rodriguez, A.Z.; Wang, H.; Hu, L.; Zhang, Y.; Xu, P. Treatment of Produced Water in the Permian Basin for Hydraulic Fracturing: Comparison of Different Coagulation Processes and Innovative Filter Media. Water 2020, 12, 770. [CrossRef]

26. Smith, K.A. Fundamentals of Momentum, Heat and Mass; Welty, J.R., Wicks, C.E., Wilson R.E., Eds.; Wiley: Hoboken, NJ, USA, 1976; Volume 789, pp. 27-55. Fundamental Principles of Heat; Whetaker, S., Ed.; Cambridge University Press: Cambridge, UK, 1978; pp. 793-794. [CrossRef]

27. Do, D.D. Adsorption Analysis: Equilibria and Kinetics. Published by Imperial College Press and Distributed by World Scientific Publishing CO. 1998. Available online: http://xxx.lanl.gov/abs/https: / /www.worldscientific.com/ (accessed on 15 February 2020).

28. Králik, M. Adsorption, chemisorption, and catalysis. Chem. Pap. 2014, 68. [CrossRef]

29. Nethaji, S.; Sivasamy, A.; Mandal, A.B. Adsorption isotherms, kinetics and mechanism for the adsorption of cationic and anionic dyes onto carbonaceous particles prepared from Juglans regia shell biomass. Int. J. Environ. Sci. Technol. 2013, 10, 231-242. [CrossRef]

30. Largitte, L.; Pasquier, R. A review of the kinetics adsorption models and their application to the adsorption of lead by an activated carbon. Chem. Eng. Res. Des. 2016, 109, 495-504. [CrossRef] 
31. Foo, K.Y.; Hameed, B. An overview of dyes removal via activated carbon adsorption process. Desalin. Water Treat. 2011, 19, 255-274. [CrossRef]

32. Ho, Y.; McKay, G. Pseudo-second order model for sorption processes. Process. Biochem. 1999, 34, 451-465. [CrossRef]

33. Eren, Z.; Acar, F.N. Adsorption of Reactive Black 5 from an aqueous solution: Equilibrium and kinetic studies. Desalination 2006, 194, 1-10. [CrossRef]

34. Cheung, C.W.; Porter, J.F.; McKay, G. Elovich equation and modified second-order equation for sorption of cadmium ions onto bone char. J. Chem. Technol. Biotechnol. 2000, 75, 963-970. [CrossRef]

35. Allen, S.J.; Brown, P.A. Isotherm analyses for single component and multi-component metal sorption onto lignite. J. Chem. Technol. Biotechnol. 1995, 62, 17-24. [CrossRef]

36. Weber, W.J.; Morris, J.C. Kinetics of Adsorption on Carbon from Solution. J. Sanit. Eng. Div. 1963, 89, 31-60.

37. Wainipee, W.; Weiss, D.J.; Sephton, M.A.; Coles, B.J.; Unsworth, C.; Court, R. The effect of crude oil on arsenate adsorption on goethite. Water Res. 2010, 44, 5673-5683. [CrossRef]

38. Franco, C.A.; Nassar, N.N.; Cortés, F.B. Removal of oil from oil-in-saltwater emulsions by adsorption onto nano-alumina functionalized with petroleum vacuum residue. J. Colloid Interface Sci. 2014, 433, 58-67. [CrossRef]

39. Fard, A.K.; Rhadfi, T.; Mckay, G.; Al-marri, M.; Abdala, A.; Hilal, N.; Hussien, M.A. Enhancing oil removal from water using ferric oxide nanoparticles doped carbon nanotubes adsorbents. Chem. Eng. J. 2016, 293, 90-101. [CrossRef]

40. Moura, C.P.; Vidal, C.B.; Barros, A.L.; Costa, L.S.; Vasconcellos, L.C.; Dias, F.S.; Nascimento, R.F. Adsorption of BTX (benzene, toluene, o-xylene, and p-xylene) from aqueous solutions by modified periodic mesoporous organosilica. J. Colloid Interface Sci. 2011, 363, 626-634. [CrossRef]

41. El-Naas, M.H.; Al-Zuhair, S.; Alhaija, M.A. Reduction of COD in refinery wastewater through adsorption on date-pit activated carbon. J. Hazard. Mater. 2010, 173, 750-757. [CrossRef] [PubMed]

42. Cortés, F. Water Remediation Based on Oil Adsorption Using Nanosilicates Functionalized with a Petroleum Vacuum Residue. Adsorpt. Sci. Technol. 2014, 32, 197-207.

43. Kunjirama, M.; Saman, N.; Johari, K.; Song, S.T.; Kong, H.; Cheu, S.C.; Lye, J.; Mat, H. Adsorption affinity and selectivity of 3-ureidopropyltriethoxysilane grafted oil palm empty fruit bunches towards mercury ions. Environ. Sci. Pollut. Res. Int. 2017, 24. [CrossRef]

44. Lagergren, S. Zur Theorie der Sogenannten Adsorption Gelöster Stoffe; Kungliga Svenska Vetenskapsakad; Handlingar Bihang: Stockholm, Sweden, 1898.

45. Ho, Y.S. Review of second-order models for adsorption systems. J. Hazard. Mater. 2006, 136, 681-689. [CrossRef] [PubMed]

46. Annadurai, G.; Juang, R.S.; Lee, D.J. Use of cellulose-based wastes for adsorption of dyes from aqueous solutions. J. Hazard. Mater. 2002, 92, 263-274. [CrossRef]

47. El-Khaiary, M.I. Least-squares regression of adsorption equilibrium data: Comparing the options. J. Hazard. Mater. 2008, 158, 73-87. [CrossRef] [PubMed]

48. Ge, M.; Xi, Z.; Zhu, C.; Liang, G.; Yang, Y.; Hu, G.; Jamal, L.; S.M., J.A. Adsorption Process and Properties Analyses of a Pure Magadiite and a Modified Magadiite on Rhodamine-B from an Aqueous Solution. Processes 2019, 7, 565. [CrossRef]

49. Wong, Y.; Szeto, Y.; Cheung, W.; McKay, G. Adsorption of acid dyes on chitosan equilibrium isotherm analyses. Process. Biochem. 2004, 39, 695-704. [CrossRef]

50. Langmuir, I. The Constitution and Fundamental Properties of Solids and Liquids. II. liquids.1. J. Am. Chem. Soc. 1917, 39, 1848-1906. [CrossRef]

51. Freundlich, H. Over the adsorption in solution. Phys. Chem. 1906, 57, 385-471.

52. Sips, R. On the Structure of a Catalyst Surface. J. Chem. Phys. 1948, 16, 490-495. [CrossRef]

53. Dubinin, M.M. The Potential Theory of Adsorption of Gases and Vapors for Adsorbents with Energetically Nonuniform Surfaces. Chem. Rev. 1960, 60, 235-241. [CrossRef]

54. Tempkin, M.; Pyzhev, V. Recent modifications to Langmuir isotherms. Acta Physiochim. URSS 2020, 12, 217-222.

55. Al.Haddabi, M.; Znad, H.; Ahmed, M. Removal of Dissolved Organic Carbon from Oily Produced Water by Adsorption onto Date Seeds: Equilibrium, Kinetic, and Thermodynamic Studies. Water Air Soil Pollut. 2015, 226. [CrossRef] 
56. De Caprariis, B.; Filippis, P.D.; Hernandez, A.D.; Petrucci, E.; Petrullo, A.; Scarsella, M.; Turchi, M. Pyrolysis wastewater treatment by adsorption on biochars produced by poplar biomass. J. Environ. Manag. 2017, 197, 231-238. [CrossRef] [PubMed]

57. Kaveeshwar, A.R.; Ponnusamy, S.K.; Revellame, E.D.; Gang, D.D.; Zappi, M.E.; Subramaniam, R. Pecan shell based activated carbon for removal of iron(II) from fracking wastewater: Adsorption kinetics, isotherm and thermodynamic studies. Process. Saf. Environ. Prot. 2018, 114, 107-122. [CrossRef]

58. Albatrni, H.; Qiblawey, H.; Almomani, F.; Adham, S.; Khraisheh, M. Polymeric adsorbents for oil removal from water. Chemosphere 2019, 233, 809-817. [CrossRef] [PubMed]

59. Foo, K.; Hameed, B. Insights into the modeling of adsorption isotherm systems. Chem. Eng. J. 2010, 156, 2-10. [CrossRef]

60. Adamson, A.; Gast, A. Physical Chemistry of Liquid Surfaces; Interscience Publishers: New York, NY, USA, 1970; pp. 44-116. [CrossRef]

61. Haghseresht, F.; Lu, G.Q. Adsorption Characteristics of Phenolic Compounds onto Coal-Reject-Derived Adsorbents. Energy Fuels 1998, 12, 1100-1107. [CrossRef]

62. Ho, Y.S.; Porter, J.F.; McKay, G. Equilibrium Isotherm Studies for the Sorption of Divalent Metal Ions onto Peat: Copper, Nickel and Lead Single Component Systems. Water Air Soil Pollut. 2002, 141, 1-33. [CrossRef]

63. Chen, S.G.; Yang, R.T. Theoretical Basis for the Potential Theory Adsorption Isotherms. The DubininRadushkevich and Dubinin-Astakhov Equations. Langmuir 1994, 10, 4244-4249. [CrossRef]

64. Crisafully, R.; Milhome, M.A.L.; Cavalcante, R.M.; Silveira, E.R.; Keukeleire, D.D.; Nascimento, R.F. Removal of some polycyclic aromatic hydrocarbons from petrochemical wastewater using low-cost adsorbents of natural origin. Bioresour. Technol. 2008, 99, 4515-4519. [CrossRef]

65. Bury, N.R.; Boyle, D.; Cooper, C.A. 4-Iron. In Homeostasis and Toxicology of Essential Metals; Wood, C.M., Farrell, A.P., Brauner, C.J., Eds.; Academic Press: Cambridge, MA, USA, 2011; Volume 31, pp. 201-251. [CrossRef]

66. Pearson, G.; Boyd, F.; Haggerty, S.; Pasteris, J.; Field, S.; Nixon, P.; Pokhilenko, N. The characterisation and origin of graphite in cratonic lithospheric mantle: A petrological carbon isotope and Raman spectroscopic study. Contrib. Mineral. Petrol. 1994, 115, 449-466. [CrossRef]

67. Takeuchi, K.; Fujishige, M.; Kitazawa, H.; Akuzawa, N.; Medina, J.O.; Morelos-Gomez, A.; Cruz-Silva, R.; Araki, T.; Hayashi, T.; Terrones, M.; et al. Oil sorption by exfoliated graphite from dilute oil-water emulsion for practical applications in produced water treatments. J. Water Process. Eng. 2015, 8, 91-98. [CrossRef]

68. Gautam, R.K.; Verma, A. Chapter 3.4-Electrocatalyst Materials for Oxygen Reduction Reaction in Microbial Fuel Cell. In Microbial Electrochemical Technology; Mohan, S.V., Varjani, S., Pandey, A., Eds.; Elsevier: Amsterdam, The Netherlands, 2019; pp. 451-483. [CrossRef]

69. Saleh, T.A.; Sarı, A.; Tuzen, M. Effective adsorption of antimony(III) from aqueous solutions by polyamide-graphene composite as a novel adsorbent. Chem. Eng. J. 2017, 307, 230-238. [CrossRef]

70. Sparks, D.L. 2-Inorganic Soil Components. In Environmental Soil Chemistry, 2nd ed.; Sparks, D.L., Ed.; Academic Press: Cambridge, MA, USA, 2003; pp. 43-73. [CrossRef]

71. Ross, C.S.; Shannon, E.V. The Minerals of Bentonite and Related Clays and Their Physical Properties. J. Am. Ceram. Soc. 1926, 9, 77-96. [CrossRef]

72. He, H.; Zhu, J. Chapter 10-Analysis of Organoclays and Organic Adsorption by Clay Minerals. In Infrared and Raman Spectroscopies of Clay Minerals; Gates, W., Kloprogge, J., Madejová, J., Bergaya, F., Eds.; Elsevier: Amsterdam, The Netherlands, 2017; Volume 8, pp. 310-342. [CrossRef]

73. Wimpenny, J. Clay Minerals. In Encyclopedia of Geochemistry: A Comprehensive Reference Source on the Chemistry of the Earth; White, W.M., Ed.; Springer: Cham, Switzerland, 2016; pp. 1-11. [CrossRef]

74. Zheng, Y.; Liu, W.; Wang, Q.; Sun, Y.; Li, G.; Wu, T.; Li, Y. Study of STAB- and DDAB-modified sepiolite tructures and their adsorption performance for emulsified oil in produced water. Colloid Interface Sci. Commun. 2020, 34, 100231. [CrossRef]

75. Sueyoshi, M.; Al-Maamari, R.S.; Jibril, B.; Tasaki, M.; Okamura, K.; Kuwagaki, H.; Yahiro, H.; Sagata, K.; Han, Y. Preparation and characterization of adsorbents for treatment of water associated with oil production. J. Anal. Appl. Pyrolysis 2012, 97, 80-87. [CrossRef]

76. Okiel, K.; El-Sayed, M.; El-Kady, M.Y. Treatment of oil-water emulsions by adsorption onto activated carbon, bentonite and deposited carbon. Egypt. J. Pet. 2011, 20, 9-15. [CrossRef] 
77. Emam, E. Modified Activated Carbon and Bentonite Used to Adsorb Petroleum Hydrocarbons Emulsified in Aqueous Solution. Am. J. Environ. Prot. 2013, 2, 161. [CrossRef]

78. Liu, D.; Xu, Y.; Papineau, D.; Yu, N.; Fan, Q.; Qiu, X.; Wang, H. Experimental evidence for abiotic formation of low-temperature proto-dolomite facilitated by clay minerals. Geochim. Cosmochim. Acta 2019, 247, 83-95. [CrossRef]

79. Vasconcelos, C.; Mckenzie, J.; Bernasconi, S.; Grujic, D.; Tien, A. Microbial Mediation as a Possible Mechanism for Natural Dolomite Formation at Low-Temperatures. Nature 1995, 377, 220-222. [CrossRef]

80. Ghaemi, A.; Torab-Mostaedi, M.; Ghannadi-Maragheh, M. Characterizations of strontium(II) and barium(II) adsorption from aqueous solutions using dolomite powder. J. Hazard. Mater. 2011, 190, 916-921. [CrossRef]

81. Shahruddin, M.Z.; Othman, N.H.; Alias, N.H.; Ghani, S.N.A. Desalination of Produced Water Using Bentonite as Pre-Treatment and Membrane Separation as Main Treatment. Procedia Soc. Behav. Sci. 2015, 195, 2094-2100. [CrossRef]

82. Younker, J.M.; Walsh, M.E. Bench-scale investigation of an integrated adsorption-coagulation-dissolved air flotation process for produced water treatment. J. Environ. Chem. Eng. 2014, 2, 692-697. [CrossRef]

83. Younker, J.M.; Walsh, M.E. Impact of salinity and dispersed oil on adsorption of dissolved aromatic hydrocarbons by activated carbon and organoclay. J. Hazard. Mater. 2015, 299, 562-569. [CrossRef]

84. Elsherif, K.; Alkherraz, A.; Ali, A. Removal of $\mathrm{Pb}(\mathrm{II}), \mathrm{Zn}(\mathrm{II}), \mathrm{Cu}(\mathrm{II})$ and $\mathrm{Cd}(\mathrm{II})$ from aqueous solutions by adsorption onto olive branches activated carbon: Equilibrium and thermodynamic studies. Chem. Int. 2019, 6, 11-20. [CrossRef]

85. Araújo, C.S.; Almeida, I.L.; Rezende, H.C.; Marcionilio, S.M.; Léon, J.J.; de Matos, T.N. Elucidation of mechanism involved in adsorption of $\mathrm{Pb}(\mathrm{II})$ onto lobeira fruit (Solanum lycocarpum) using Langmuir, Freundlich and Temkin isotherms. Microchem. J. 2018, 137, 348-354. [CrossRef]

86. Khan, S.; Ali, J. 2-Chemical analysis of air and water. In Bioassays; Häder, D.P., Erzinger, G.S., Eds.; Elsevier: Amsterdam, The Netherlands, 2018; pp. 21-39. [CrossRef]

87. El-Naas, M.; Sulaiman, A.Z.; Alhaija, M. Removal of Phenol from Petroleum Refinery Wastewater through Adsorption on Date-Pit Activated Carbon. Chem. Eng. J. 2010, 162, 997-1005. [CrossRef]

88. El-Nafaty, U.; Misau, I.; Abdulsalam, S. Biosorption and Kinetic Studies on Oil Removal from Produced Water Using Banana Peel. Civ. Environ. Res. 2013, 3, 125-136.

89. Ibrahim, T.; Gulistan, A.; Khamis, M.; Ahmed, H.; Aidan, A. Produced water treatment using naturally abundant pomegranate peel. Desalin. Water Treat. 2016, 57, 6693-6701. [CrossRef]

90. Shakya, A.; Agarwal, T. Removal of $\mathrm{Cr}(\mathrm{VI})$ from water using pineapple peel derived biochars: Adsorption potential and re-usability assessment. J. Mol. Liq. 2019, 293, 111497. [CrossRef]

91. Song, S.T.; Saman, N.; Johari, K.; Mat, H. Surface chemistry modifications of rice husk toward enhancement of $\mathrm{Hg}(\mathrm{II})$ adsorption from aqueous solution. Clean Technol. Environ. Policy 2014, 16, 1747-1755. [CrossRef]

92. Shen, Z.; Zhang, Y.; McMillan, O.; Jin, F.; Al-Tabbaa, A. Characteristics and mechanisms of nickel adsorption on biochars produced from wheat straw pellets and rice husk. Environ. Sci. Pollut. Res. 2017. [CrossRef] [PubMed]

93. Kudaibergenov, K.; Ongarbayev, Y.; Mansurov, Z.; Yerlan, D. Study on the effectiveness of thermally treated rice husks for petroleum adsorption. J. Non-Cryst. Solids 2012, 358, 2964-2969. [CrossRef]

94. Shi, Y.; Hu, H.; Ren, H. Dissolved organic matter (DOM) removal from biotreated coking wastewater by chitosan-modified biochar: Adsorption fractions and mechanisms. Bioresour. Technol. 2020, 297, 122281. [CrossRef] [PubMed]

95. Li, B.; Yang, L.; Wang, C.Q.; Zhang, Q.P.; Liu, Q.C.; Li, Y.D.; Xiao, R. Adsorption of Cd(II) from aqueous solutions by rape straw biochar derived from different modification processes. Chemosphere 2017, 175, 332-340. [CrossRef] [PubMed]

96. Chi, T.; Zuo, J.E.; Liu, F. Performance and mechanism for cadmium and lead adsorption from water and soil by corn straw biochar. Front. Environ. Sci. Eng. 2017, 11, 15. [CrossRef]

97. Peng, H.; Gao, P.; Chu, G.; Pan, B.; Peng, J.; Xing, B. Enhanced adsorption of Cu(II) and Cd(II) by phosphoric acid-modified biochars. Environ. Pollut. 2017, 229, 846-853. [CrossRef]

98. Iranmanesh, S.; Harding, T.; Abedi, J.; Seyedeyn-Azad, F.; Layzell, D. Adsorption of naphthenic acids on high surface area activated carbons. J. Environ. Sci. Health 2014, 49, 913-922. [CrossRef]

99. Behnood, R.; Anvaripour, B.; Fard, N.; Farasati, M. Petroleum hydrocarbons adsorption from aqueous solution by raw sugarcane bagasse. Int. J. Emerg. Sci. Eng. 2013, 1, 96-99. 
100. Venkatesan, J.; Kim, S. 10-Chitosan for bone repair and regeneration. In Bone Substitute Biomaterials; Mallick, K., Ed.; Woodhead Publishing Series in Biomaterials; Woodhead Publishing: Cambridge, UK, 2014; pp. 244-260. [CrossRef]

101. Grem, I.; Lima, B.; Carneiro, W.; Queiros, Y.; Mansur, C. Chitosan Microspheres Applied for Removal of Oil from Produced Water in the Oil Industry. Polimeros Ciência Tecnol. 2013, 23, 705-711. [CrossRef]

102. Hosny, R.; Fathy, M.; Ramzi, M.; Moghny, T.A.; Desouky, S.; Shama, S. Treatment of the oily produced water (OPW) using coagulant mixtures. Egypt. J. Pet. 2016, 25, 391-396. [CrossRef]

103. Misau, I.; El-Nafaty, U.; Abdulsalam, S.; Isa, Y. Removal of Oil from Oil Produced Water Using Eggshell. Civ. Environ. Res. 2012, 2, 52-63.

104. Alqadami, A.A.; Khan, M.A.; Otero, M.; Siddiqui, M.R.; Jeon, B.H.; Batoo, K.M. A magnetic nanocomposite produced from camel bones for an efficient adsorption of toxic metals from water. J. Clean. Prod. 2018, 178, 293-304. [CrossRef]

105. Yuan, M.; Tong, S.; Zhao, S.; Jia, C.Q. Adsorption of polycyclic aromatic hydrocarbons from water using petroleum coke-derived porous carbon. J. Hazard. Mater. 2010, 181, 1115-1120. [CrossRef]

106. Asenjo, N.G.; Álvarez, P.; Granda, M.; Blanco, C.; Santamaría, R.; Menéndez, R. High performance activated carbon for benzene/toluene adsorption from industrial wastewater. J. Hazard. Mater. 2011, 192, 1525-1532. [CrossRef]

107. Björklund, K.; Li, L.Y. Adsorption of organic stormwater pollutants onto activated carbon from sewage sludge. J. Environ. Manag. 2017, 197, 490-497. [CrossRef] [PubMed]

108. An, C.; Yang, S.; Huang, G.; Zhao, S.; Zhang, P.; Yao, Y. Removal of sulfonated humic acid from aqueous phase by modified coal fly ash waste: Equilibrium and kinetic adsorption studies. Fuel 2016, 165, $264-271$. [CrossRef]

109. Jung, K.; Oh, S.; Bak, H.; Song, G.H.; Kim, H.T. Adsorption of Arsenic and Lead onto Stone Powder and Chitosan-Coated Stone Powder. Processes 2019, 7, 599. [CrossRef]

110. Abdel-Shafy, H.I.; Mansour, M.S.; El-Toony, M.M. Integrated treatment for oil free petroleum produced water using novel resin composite followed by microfiltration. Sep. Purif. Technol. 2020, 234, 116058. [CrossRef]

111. Konggidinata, M.I.; Chao, B.; Lian, Q.; Subramaniam, R.; Zappi, M.; Gang, D.D. Equilibrium, kinetic and thermodynamic studies for adsorption of BTEX onto Ordered Mesoporous Carbon (OMC). J. Hazard. Mater. 2017, 336, 249-259. [CrossRef]

112. Jang, Y.; Chung, E. Adsorption of Lithium from Shale Gas Produced Water Using Titanium Based Adsorbent. Ind. Eng. Chem. Res. 2018, 57, 8381-8387. [CrossRef]

113. Khan, I.; Saeed, K.; Khan, I. Nanoparticles: Properties, applications and toxicities. Arab. J. Chem. 2019, 12, 908-931. [CrossRef]

114. Laurent, S.; Forge, D.; Port, M.; Roch, A.; Robic, C.; Vander Elst, L.; Muller, R.N. Magnetic Iron Oxide Nanoparticles: Synthesis, Stabilization, Vectorization, Physicochemical Characterizations, and Biological Applications. Chem. Rev. 2008, 108, 2064-2110. [CrossRef] [PubMed]

115. Fard, A.K.; Mckay, G.; Manawi, Y.; Malaibari, Z.; Hussien, M.A. Outstanding adsorption performance of high aspect ratio and super-hydrophobic carbon nanotubes for oil removal. Chemosphere 2016, 164, 142-155. [CrossRef] [PubMed]

116. Masomeh, S.; Masooleh, S.; Bazgir, S.; Tamizifar, M. Adsorption of petroleum hydrocarbons on organoclay. J. Appl. Chem. Res. 2010, 4, 19-23.

117. Fard, A.K.; Mckay, G.; Chamoun, R.; Rhadfi, T.; Preud'Homme, H.; Atieh, M.A. Barium removal from synthetic natural and produced water using MXene as two dimensional (2-D) nanosheet adsorbent. Chem. Eng. J. 2017, 317, 331-342. [CrossRef]

118. Reddy, K.; McDonald, K.; King, H. A novel arsenic removal process for water using cupric oxide nanoparticles. J. Colloid Interface Sci. 2013, 397, 96-102. [CrossRef] [PubMed]

119. Yen, C.H.; Lien, H.L.; Chung, J.S.; Yeh, H.D. Adsorption of precious metals in water by dendrimer modified magnetic nanoparticles. J. Hazard. Mater. 2017, 322, 215-222. [CrossRef]

120. Belbase, S.; Urynowicz, M.A.; Vance, G.F.; Dangi, M.B. Passive remediation of coalbed natural gas co-produced water using zeolite. J. Environ. Manag. 2013, 131, 318-324. [CrossRef]

121. Ma, J.; Wang, Y.; Stevens, G.W.; Mumford, K.A. Hydrocarbon adsorption performance and regeneration stability of diphenyldichlorosilane coated zeolite and its application in permeable reactive barriers: Column studies. Microporous Mesoporous Mater. 2020, 294, 109843. [CrossRef] 
122. Rosenblum, J.S.; Sitterley, K.A.; Thurman, E.M.; Ferrer, I.; Linden, K.G. Hydraulic fracturing wastewater treatment by coagulation-adsorption for removal of organic compounds and turbidity. J. Environ. Chem. Eng. 2016, 4, 1978-1984. [CrossRef]

123. El-Naas, M.; Alhaija, M.; Sulaiman, A.Z. Evaluation of an activated carbon packed bed for the adsorption of phenols from petroleum refinery wastewater. Environ. Sci. Pollut. Res. 2017, 24. [CrossRef] [PubMed]

Publisher's Note: MDPI stays neutral with regard to jurisdictional claims in published maps and institutional affiliations.

(c) 2020 by the authors. Licensee MDPI, Basel, Switzerland. This article is an open access article distributed under the terms and conditions of the Creative Commons Attribution (CC BY) license (http://creativecommons.org/licenses/by/4.0/). 